\title{
Notes
}

\section{Gray Wolf (Canis lupus) Movements and Behavior Around a Kill Site and Implications for GPS Collar Studies}

\author{
L. DAVID MECH ${ }^{1,2}$
}

${ }^{1}$ U.S. Geological Survey, Northern Prairie Wildlife Research Center, 8711 - 37th Street SE, Jamestown, North Dakota 584017317 USA; email: david_mech@usgs.gov

${ }^{2}$ Mailing address: Raptor Center, 1920 Fitch Avenue, University of Minnesota, St. Paul, Minnesota 55108 USA

Mech, L. David. 2011. Gray Wolf (Canis lupus) movements and behavior around a kill site and implications for GPS collar studies. Canadian Field-Naturalist 125(4): 353-356.

Global Positioning System (GPS) radio-collars are increasingly used to estimate Gray Wolf (Canis lupus) kill rates. In interpreting results from this technology, researchers make various assumptions about wolf behavior around kills, yet no detailed description of this behavior has been published. This article describes the behavior of six wolves in an area of constant daylight during 30 hours, from when the pack killed a Muskox (Ovibos moschatus) calf and yearling on Ellesmere Island, Nunavut, Canada, to when they abandoned the kill remains. Although this is only a single incident, it demonstrates one possible scenario of pack behavior around a kill. Combined with the literature, this observation supports placing a radio-collar on the breeding male to maximize finding kills via GPS collars and qualifying results depending on whatever other information is available about the collared wolf's pack.

Key Words: Behavior, Gray Wolf, Canis lupus, Muskox, Ovibos moschatus, global positioning system collar, GPS radio-collar, predation, Ellesmere Island, Nunavut.

The use of Global Positioning System (GPS) radiocollars on Gray Wolves (Canis lupus) (Mech et al. 1998; Merrill et al. 1998) soon led to attempts to study wolf predation (Sand et al. 2005; Demma et al. 2007; Zimmerman et al. 2007; Sand et al. 2008; Webb et al. 2008; Palacios and Mech 2010). Such attempts rely on the assumption that when wolves make a kill, they remain at or near the kill for a long enough period so that clusters of the GPS locations taken from the kill site can be distinguished from GPS locations recorded while the animals are traveling. Usually candidate kill locations are ground-truthed using a hand-held GPS system to locate and search the clusters for kill remains and evidence of wolf presence after the wolves have left.

Although researchers have used this technique successfully to locate kills and estimate kill rates, the correct interpretation of the findings depends on assumptions about wolf behavior around kill sites. Wolves usually function in packs, especially in winter, yet rarely do researchers place a radio-collar on every pack member. In fact, collars are usually placed on only one or two pack members (Demma et al. 2007; Zimmerman et al. 2007; Sand et al. 2008; Metz et al. 2011), even though wolf packs can include 15 or more individuals (Mech 1970). Thus kills and travels of a wolf with a GPS radio-collar strictly pertain to that wolf and not necessarily to the entire pack. Assumptions that such data describe the behavior of an entire pack require verification from the field (Metz et al. 2011).

Correct interpretation of information about wolf kills thus requires accurate knowledge about the behavior of wolf packs around their kills. However, most wolf kills are large, so much of the time that wolves spend in association with a kill is at night, when it has not been possible to observe the wolves' movements and behavior. With smaller kills, such as White-tailed deer (Odocoileus virginianus), a large pack of wolves may consume a kill in a few hours and move on, so two aerial visits in a day might be required just to determine kill rate (Fuller 1989). With larger prey, such as Moose (Alces alces), packs may feed for as many as three days on a single kill, and all or part of the pack might leave the kill a few times, rest miles away, and return periodically (Mech 1966). The details of wolf movements and behavior around kills have never been reported from beginning to end. Information about such behavior would be valuable to allow a more complete understanding of data obtained via GPS radio-telemetry. Only one attempt has been made to assess the effect of Gray wolf behavior around kills on the results of a GPS study of Gray wolf kill rate (Metz et al. 2011).

This article describes the behavior of a pack of six wolves around the kill of a Muskox (Ovibos moschatus) calf and yearling in an area of 24-hour daylight, from the moment of the kill to when the pack left it, 30 hours later. The observation represents one scenario, which, when combined with other observations, can improve the accuracy of interpreting data on kill rates derived from GPS radio-collars.

\section{Study Area}

This study was conducted on the Fosheim Peninsula on the west side of Ellesmere Island, Nunavut, Canada $\left(80^{\circ} \mathrm{N}, 86^{\circ} \mathrm{W}\right)$. The area includes hills, lowlands, creek 
bottoms, ridges, and considerable uneven terrain with many dips and trenches. Unlike much of the surrounding region, this area is generally free of permanent snow and ice in July and August and contains rock, gravel, bare soil, scattered tundra, and northern wetland vegetation. However, fresh snow can cover the ground at any time (Mech 2004). Wolves, Muskoxen, and Arctic Hares (Lepus arcticus) are common in the area (Tener 1954). wolves have denned in this region for decades or possibly centuries (Parmelee 1964; Grace 1976; Mech 1988; Mech and Packard 1990). The main foods of the wolves are Muskoxen (especially calves during summer), Arctic Hares (Tener 1954), and occasionally Caribou (Rangifer tarandus) and seals (Phoca spp.).

\section{Methods}

Wolves in the study area have long been unafraid of humans (Parmelee 1964; Grace 1976; Mech 1988). During the present study, a pack of eight allowed me to observe them from within a few meters and to accompany them on all-terrain vehicles (ATVs) when they were traveling (Mech 1994). Thus observer presence was not a problem in making this observation. This pack consisted of a breeding male (based on his raised-leg urination), a female with pups at a den, a non-breeding two-year-old female, a two-year-old male, and four female yearlings (Mech 1995).

During the present study, which took place in July 1989, an associate and I had been trying to locate the current year's wolf den by finding the pack and following it on all-terrain vehicles. When we located the pack on 4 July, the two adult females were not with it. The rest of the pack was about to attack a herd of Muskoxen. We observed them, first through binoculars, and then, after they had made their kills, we lay in a tundra depression 50-100 $\mathrm{m}$ away and observed them directly.

\section{Results}

Following are lightly edited field notes of our observations, including for context the behavior of the wolves just before and after the kill period:

At 1320 , the wolves switched direction and headed southwest up a hill where I could see several Muskox herds 1-2 km away. The wolves quickly got to the nearest herd (nine adults and two calves) $800 \mathrm{~m}$ away, and at 1325 looked intently at the herd from a distance of about $200 \mathrm{~m}$, but the herd was already tightly grouped. Both wolves and Muskoxen lay down 1325-1405. Then the Muskoxen grouped tighter, and the wolves left.

The wolves continued west up a hill and disappeared, and it took us a while to catch up to them. When we did, we came to a river gully draining the west mountains and saw the wolves and various Muskoxen on a flat on the west side. There was a group of four cows and three calves grouped very tightly and about $200 \mathrm{~m}$ away a herd of nine cows and three calves. In between, about $50 \mathrm{~m}$ from the smaller herd, stood a calf apparently confused about which way to turn. The six wolves sped by the larger herd and headed straight to the calf. They all then grabbed the calf around the head as usual and pulled it down (1422). The wolves killed the calf within about 5 minutes.

Then I noticed about $50 \mathrm{~m}$ straight ahead of us (the rest of the action was taking place to our right and ahead) what turned out to be a yearling Muskox already wounded in the nose. The wolves came back and worked on it, grabbing it mostly by the hind legs until they had it down. They killed that animal within about 5 minutes also and began feeding on it (1437).

After killing the yearling and calf and running back and forth between them, the wolves noticed a single bull that we had seen "hiding" in the creek gully, which was about $25 \mathrm{~m}$ wide and $4 \mathrm{~m}$ deep, run up the bank and try to get to the herd of nine cows and three calves. The wolves headed straight toward him and tried to attack, but the bull whirled and charged them, and within 30-60 seconds, the wolves had given up, and the bull got into the herd.

This may not have been this bull's herd, however. There were two other adults elsewhere in the gulley that also came up and joined the larger herd. The wolves tried to attack them also but gave up quickly.

The whole herd (now consisting of nine cows, three calves, two adults, and one bull) then began gradually to drift away from the wolves, which were feeding about $150 \mathrm{~m}$ away. As the herd moved away, individuals became anxious and began to move faster. Soon the whole herd was running toward the gulley. Instantly the wolves stopped feeding and headed straight toward the herd, which fled across the gulley and then stood on top of the east bank and fought off the wolves.

(My whole impression of the overall area is that the terrain helped the wolves. Perhaps they used the gullies to get close to the Muskoxen. There must have been quite a bit of surprise and confusion when the wolves arrived, since the calf had been left out alone, the bull was caught alone in the gully, and the two other adults were in the gully, all separated from the two herds.)

The last wolf stopped feeding on the calf at 1552 . At 1600 , one wolf came to the yearling, ate a few bites, and then headed southeast across the gully and disappeared at 1605 .

The wolves slept and rested individually around and between the kills after feeding. At 1615, however, the breeding male arose and headed to a few other wolves and they licked up to him and trooped with him [licked him around the mouth and walked excitedly with him in a close-knit group] and he took them back to the calf carcass, where they fed again. 
The wolf that had left and gone toward the southeast returned at 1705 , and the other five wolves greeted it.

The wolves then slept until 2118, when a female yearling awoke, squat urinated, and howled six times; all the others then arose, three squat urinated, and the pack headed across the gully to the southeast. We followed at 2126 . They went only about $150 \mathrm{~m}$ and rested. The first two turned around, and all six then headed back to the yearling kill, which was only $10-20 \%$ eaten. Only two fed on it, then just one, and the rest remained around the general area from 2220 to 2316 .

At 2316, the wolves arose and played and slept on the bank across from the kill. One wolf left at 2330 and headed east. My associate crossed the gully and watched with binoculars. The yearling female left at 2350 and my associate watched her. One went to Eastwind Lake and back, and the other chased Muskox herds near Eastwind Lake.

The breeding male fed on the yearling Muskox and took part off and fed on it. (Two yearlings fed off and on from the yearling carcass until 1310 the next day [July 5].)

At 0020 on July 5, the breeding male looked east and howled intermittently. Then he went back to sleep 0030-0055. He got up again, changed spots, looked east and southeast, and slept again. At 0056, one yearling headed southeast and rolled in the snow and another one looked southeast intently.

One wolf returned from the southeast at 0104 and lay beside the breeding male and another wolf. At 0210, one Gray Wolf headed northeast up the creek and circled back. At 0214, a two-year-old wolf howled ten times. At 0221, this wolf howled seven times and got up at 0226 and met one Gray Wolf returning. At 0230, another Wolf returned.

All slept for the rest of the morning until 0729, when the breeding male arose and fed until 0805 from the yearling Muskox. Then all slept again. My associate watched from 1000 to 1230 . The breeding male fed again at 1340 for a few minutes, and two others fed with him for a while. The breeding male raised-leg urinated and fed at 1357.

All slept all afternoon until 1754, when they arose and headed to the calf kill, where they fed and rested until 2022. We checked the yearling femur marrow, and the fat had been totally depleted.

The whole pack left the kill remains at 2022 and headed east, then northeast. We lost sight until 2035, when we saw them heading northeast toward two Muskox herds and a single Muskox out on some broad flats northeast of Eastwind Lake. At 2045 the wolf pack charged a herd of five adults and one calf. The herd grouped up, and the wolves left.

At 2050-2100 they charged directly at a herd of ten adults and two calves from $\geq 200 \mathrm{~m}$ away, but the herd grouped up and the wolves gave up in a few minutes. They then headed to a single Muskox and chased it for about 5 minutes, half the time out of our view, but then gave up.

At 2115, the wolves chased two adult Muskoxen for about 2 minutes, gave up, and continued northeast towards the pass between the northeastern end of Black Top Ridge and the mountain north of it and disappeared at 2124. We left at 2130.

\section{Discussion}

During this observation, a pack of six Wolves fed on a Muskox calf and yearling off and on for 30 hours, leaving only a few bones, hair, and rumen contents. Although there is no way of knowing the weight of the Muskoxen, captive calves weigh an average of $72 \mathrm{~kg}$ when 6 months old (Reinhardt and Flood 1983), so a reasonable estimate of calf weight in July would be $30 \mathrm{~kg}$. Yearlings weigh about $98 \mathrm{~kg}$ (Alaska Department of Fish and Game 2012*). Thus the total Muskox kill mass would have been approximately $128 \mathrm{~kg}$; assuming 7\% uneaten parts (Peterson 1977), this would leave $119 \mathrm{~kg}$, or $20 \mathrm{~kg}$ of food, per wolf. The pack dedicated 30 hours to the consumption of this amount of food.

The only comparable information of this type we found was a report of two wolves eating and caching an estimated $90 \mathrm{~kg}$ of Muskox over a period of at least 28 hours and 49 minutes (Mech and Adams 1999). In that instance, the male wolf remained at or near the kill for the entire period while the (barren) female left several times to cache food as far away as $2.3-5.0 \mathrm{~km}$ (Mech and Adams 1999).

During the 30 hours of the present observation, the wolves fed and slept intermittently, and individuals, with the exception of the breeding male, left the area and returned at various times. When the breeding male left the kill scene, all the others did too, and they immediately began chasing other Muskoxen, similar to the behavior of wolves hunting Moose (Mech 1966).

A GPS radio-collar on the breeding male would have yielded location data revealing this location as a probable kill, even if the location-acquisition rate had been as little as twice per day. However, such a collar on one of the other pack members that left the kill scene intermittently might not have revealed the kills, depending on the location-acquisition rate. This information agrees with that reported by Mech and Adams (1999), Sand et al. (2006), and Metz et al. (2011).

This single set of observations provides detailed information that will be useful in interpreting GPS data and suggests that additional observations of wolves over long, continuous periods would also help researchers better interpret GPS data. Such observations should be made of packs of various sizes killing various prey during all seasons. 


\section{Acknowledgements}

This study was funded by the National Geographic Society. I also thank Mary Maule for field assistance and Environment Canada and the Polar Continental Shelf Project for logistical support, the U.S. Geological Survey for supporting the preparation of this article, and Petter Wabakken and David Stoner for helpful suggestions for improving the article. This is Polar Continental Shelf Project paper 03010.

Documents Cited (marked $*$ in text)

Alaska Department of Fish and Game. 2012. Muskox (Ovibos moschatus). Species Profiles. http://www.adfg. alaska.gov/static/education/wns/muskox.pdf.

\section{Literature Cited}

Demma, D. J., S. M. Barber-Meyer, and L. D. Mech. 2007. Testing use of Global Positioning System telemetry to study wolf predation on deer fawns. Journal of Wildlife Management 71: 2767-2775.

Fuller, T. K. 1989. Population dynamics of wolves in northcentral Minnesota. Wildlife Monographs 105.

Grace, E. S. 1976. Interactions between men and wolves at an Arctic outpost on Ellesmere Island. Canadian FieldNaturalist 90: 149-156.

Mech, L. D. 1966. The Wolves of Isle Royale. National Parks Fauna Series No. 7. U.S. Government Printing Office, Washington, D.C. 210 pages.

Mech, L. D. 1970. The Wolf: The Ecology and Behavior of an Endangered Species. Natural History Press, Doubleday Publishing Company, New York.

Mech, L. D. 1988. The Arctic Wolf: Living with the Pack. Voyageur Press, Stillwater, Minnesota. 128 pages.

Mech, L. D. 1994. Regular and homeward travel speeds of arctic wolves. Journal of Mammalogy 75: 741-742.

Mech, L. D. 1995. A ten-year history of the demography and productivity of an arctic wolf pack. Arctic 48: 329-332.

Mech, L. D. 2004. Is climate change affecting wolf populations in the High Arctic? Climatic Change 67: 87-93.

Mech, L. D., and J. M. Packard. 1990. Possible use of wolf (Canis lupus) den over several centuries. Canadian FieldNaturalist 104: 484-485.

Mech, L. D., and L. G. Adams. 1999. Killing of a muskox, Ovibos moschatus, by two Wolves, Canis lupus, and subsequent caching. Canadian Field-Naturalist 113: 673-675.

Mech, L. D., L. G. Adams. T. J. Meier, J. W. Burch, and B. W. Dale. 1998. The Wolves of Denali. University of Minnesota Press, Minneapolis. 227 pages.
Merrill, S. B., L. G. Adams, M. E. Nelson, and L. D. Mech. 1998. Testing releasable GPS collars on wolves and whitetailed deer. Wildlife Society Bulletin 26: 830-835.

Metz, M. C., J. A. Vucetich, D. W. Smith, D. R. Stahler, and R. O. Peterson. 2011. Effect of sociality and season on gray wolf (Canis lupus) foraging behavior: Implications for estimating summer kill rate. PLoS ONE 6(3): e17332. doi:10.1371/journal.pone.0017332.

Palacios, V., and L. D. Mech. 2010. Problems with determining wolf predation on small prey in summer with global positioning system collars. European Journal of Wildlife Research 57: 149-156.

Parmelee, D. F. 1964. Myth of the wolf. The Beaver. Spring: 4-9.

R. O. Peterson. 1977. Wolf ecology and prey relationships on Isle Royale. National Park Service Scientific Monograph series 11. U.S. Government Printing Office, Washington, D. C. 210 pages.

Reinhardt, V., and P. F. Flood. 1983. Behavioural assessment in muskox calves. Behaviour 87: 1-21.

Sand, H., B. Zimmermann, P. Wabakken, H. Andren, and H. C. Pedersen. 2005. Using GPS technology and GIS cluster analyses to estimate kill rates in wolf-ungulate ecosystems. Wildlife Society Bulletin 33: 914-925.

Sand, H., C. Wikenros, P. Wabakken, and O. Liberg. 2006. Effects of hunting group size, snow depth and age on the success of wolves hunting moose. Animal Behavior 72: 781-789.

Sand, H., P. Wabakken, B. Zimmermann, O. Johansson, H. C. Pedersen, and O. Liberg. 2008. Summer kill rates and predation pattern in a wolf-moose system: Can we rely on winter estimates? Oecologia 156: 53-64.

Tener, J. S. 1954. A preliminary study of the musk-oxen of Fosheim Peninsula, Ellesmere Island, N.W.T. Canadian Wildlife Service, Wildlife Management Bulletin, Series 1, Number 9.34 pages.

Webb, N. F., M. Hebblewhite, and E. H. Merrill. 2008. Statistical methods for identifying wolf kill sites using GPS locations. Journal of Wildlife Management 72: 798807.

Zimmerman, B., P. Wabakken, H. Sand, H. C. Pedersen, and O. Liberg. 2007. Wolf movement patterns: A key to estimation of kill rate? Journal of Wildlife Management 71: 1177-1182.

Received 21 June 2011

Accepted 2 January 2012 